\title{
Connecting and Collaborating with Faculty through Curriculum Mapping
}

By Elizabeth Young Miller, Moravian College and Moravian Theological Seminary

\begin{abstract}
In my role as the seminary liaison librarian, I utilize curriculum mapping to connect and collaborate with seminary faculty. After sitting at the table during a recent curriculum review, I began mapping gatekeeping measures and course objectives to the Framework for Information Literacy for Higher Education. Partnering with teaching faculty, I flagged certain required courses and developed assessments and exercises to measure information literacy at various stages in the MATS degree program.
\end{abstract}

\section{BACKGROUND}

Before I delve into the process of curriculum mapping, I would like to provide some background on Moravian Theological Seminary. The seminary was founded in 1807 and is located in Bethlehem, Pennsylvania, about sixty miles north of Philadelphia. While Moravian by affiliation, the seminary is ecumenical in every sense-all faiths are welcome. The approximately ninety students represent sixteen denominations and faith traditions. Approximately $75 \%$ of students are enrolled parttime and about $25 \%$ bring racial and/or ethnic diversity. The seminary's website (https://www.moravianseminary.edu/) also shares that over $40 \%$ of students are over the age of fifty. Moravian offers multiple degrees: the Master of Arts in Clinical Counseling (MACC), the Master of Arts in Chaplaincy (MACh), the Master of Arts in Theological Studies (MATS), and of course, the Master of Divinity (MDiv). In addition to degree programs, the seminary offers non-degree programs and 
certificates in formative spirituality and spiritual direction. Seminary students share a library with undergraduates of Moravian College, and the library employs 6.5 full-time librarians and 3.5 full-time paraprofessionals.

Now that you have some knowledge about the institution, I would like to offer some context for the project. Before coming to Moravian, I participated in the Association of College and Research Libraries (ACRL) Assessment in Action (AiA) grant program, so I have some background in assessment. I also attended a webinar on curriculum mapping by Char Booth of Claremont University and was starting to explore this option at my previous institution. In August of 2015, I started at Moravian, and, during my first semester, paid what I have dubbed "house calls" on faculty. These house calls were scheduled one-on-one meetings with any interested faculty members. During these meetings, which lasted between sixty and ninety minutes, I attempted to get a "pulse" on the library and was particularly interested in ways to partner and collaborate, as well as discuss ideas related to information literacy and assessment. I had a sense of some things from regularly attending seminary faculty meetings, but the perspective I gained from these house calls was immeasurable. Then, in May 2016, I attended the annual two-day-long meeting at the seminary, affectionately referred to as the marathon meeting. The focus of this marathon meeting was curriculum review, in particular gating assessments for each degree program. I kept these gatekeeping measures in the back of my mind the following month as I attended my first ATLA conference in California. I was especially interested in Desirae Zingarelli-Sweet's poster titled "Prepare a Way through the Wilderness: Transforming Library Instruction by Mapping the Curriculum" and followed up with her after the conference. I eagerly began searching in the literature for information on curriculum mapping. Please see the "Resources" section of the paper for citations to useful articles I found during this process, including a citation to Desirae's poster presentation.

\section{PROCESS}

After attending the ATLA conference and reading these articles, I was excited to put ideas into practice and shared my enthusiasm 
with the dean of the seminary during a meeting in July 2016. I was working on measurable information literacy outcomes and thought curriculum mapping would be an ideal fit. My goal was to use meaningful measures for both the library and the seminary, so I explained the Framework for Information Literacy for Higher Education to the dean. Next, I pitched the idea of mapping the Framework to the curriculum, incorporating the recently approved gating assessments. The dean seemed receptive, so I asked which program I should start with. His response was MATS. The seminary's registrar then proceeded to grant me access to course syllabi, so that I could use these documents in the curriculum mapping process.

I began by creating a spreadsheet, in which I mapped the Framework to the overarching gating assessments for the MATS degree. (Please see below for more details.)

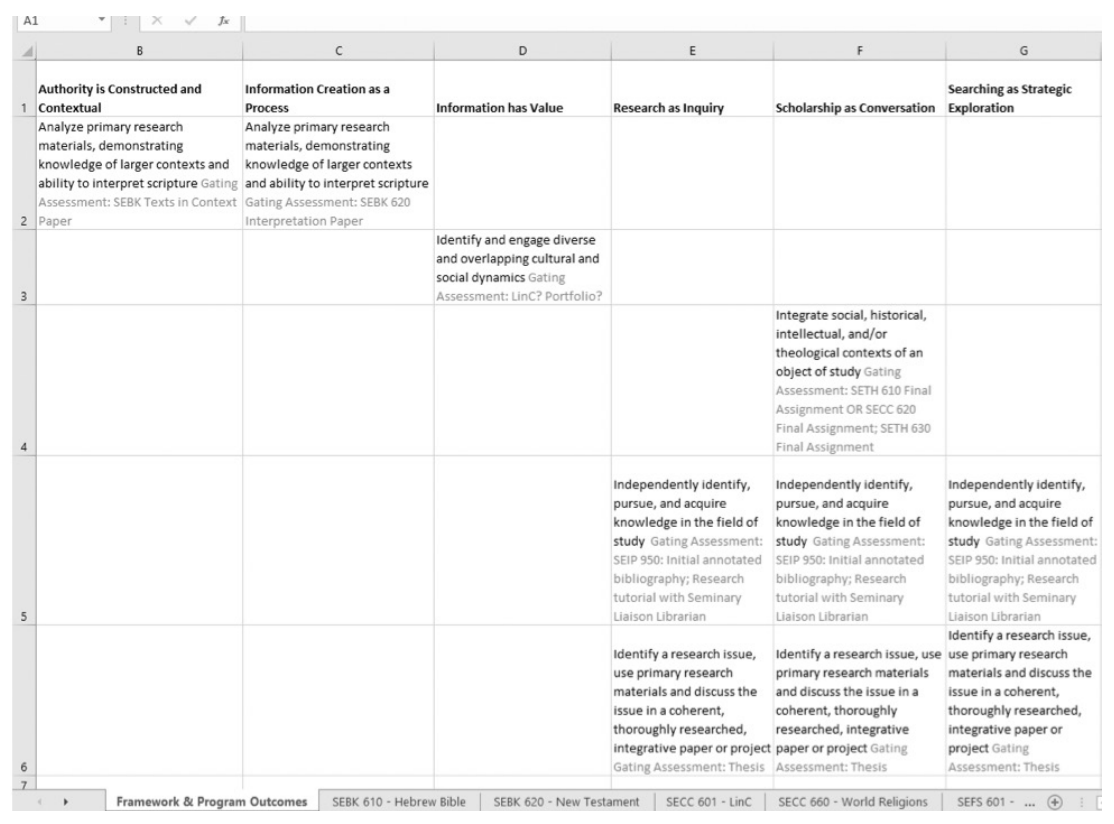

The frames are across the top of the spreadsheet. Each learning objective has its own line, and these objectives, along with the gatekeeping measures, were developed by the faculty. I mapped "Authority is Constructed and Contextual" to the Texts in Context (TiC) paper. With this assignment, faculty are looking for evidence of "[a]naly[sis] of primary research materials [that] demonstrates knowledge of larger 
contexts and the ability to interpret scripture." The faculty are looking for these same things in the New Testament interpretation paper, which I mapped to "Information Creation as a Process." I struggled with "Information has Value," but ultimately chose the course Learning in Context (LinC) or portfolio as a measure. The faculty objective paired with these measures involves "[i]dentify[ing] and engag[ing] diverse and overlapping cultural and social dynamics.” The last three frames were easier and are included for more than one frame. For example, the thesis falls under "Research as Inquiry," "Scholarship as Conversation," and "Searching as Strategic Exploration.” With the thesis, students are required to "[i]dentify a research issue, use primary research materials and discuss the issue in a coherent, thoroughly researched, integrative paper or project."

Once I mapped the gating assessments to the frames, I solicited feedback from the information literacy coordinator. She primarily works with undergraduate students and is well versed in the Framework. Once I received the green light from her, I began reviewing syllabi for all required courses for the MATS degree. You can see at the bottom of the spreadsheet, I have tabs for all these required courses-Hebrew Bible, New Testament, LinC, World Religions, etc.

I mapped course objectives listed in each syllabus to the Framework and would like to share three examples. For Intro to New Testament, the gating assessment-an interpretation paper-falls under three frames: "Authority is Constructed and Contextual," "Information Creation as a Process," and "Scholarship as Conversation." As I was working on the curriculum mapping, I attempted to develop learning outcomes as well. I also noted in the spreadsheet the presence or absence of library instruction. For this specific course, library instruction had not been included prior to my arrival. I met with this particular professor during my house calls and would like to think that perhaps this is one of the reasons that he now invites me to meet with his classes.

The second course I would like to focus on is SEIP 950, the thesis prep course. The thesis is the culminating gatekeeping assessment for the MATS degree, so it is no surprise that the course objectives tie to many of the frames. In particular, the course objective, "To present tools and opportunities to strengthen research skills," easily maps to four frames. I placed the annotated bibliography, which is a gating 
assessment, under the frame of "Scholarship as Conversation." In my attempts to meet multiple frames, the information literacy training I offer to students has expanded from one class period to two.

The third course I would like to discuss is Christian Theology. In contrast to the last two courses, this syllabus was less developed and included fewer course objectives. As a result, mapping course objectives to the frames was more challenging. Therefore, I see this particular course as a future collaboration. Currently, library instruction is not in place for this course; however, it existed under the direction of my predecessor.

In addition to identifying some future partnerships while working on this project, I have also learned more about the MATS curriculum, which has shaped collection development. For example, I ordered books listed in course syllabi that the library did not own. I have also been able to connect with professors and, hopefully, suggest titles that are relevant to their teaching. For example, I learned about the importance of womanist theology, as it relates to the Old Testament, and have been able to suggest specific titles to the Hebrew Bible professor. Collection development has been a kind of serendipitous way of connecting with faculty members and relies on faculty involvement and communication.

Throughout the curriculum mapping process, I have attempted to keep people in the loop. Open channels of communication are key in promoting collaboration, and I have been receptive to feedback and tweaks during the process. In addition to e-mail correspondence with the director of the MATS program, as well as the dean of the seminary, I have had meetings with both of these individuals and casual conversations with other faculty members, sometimes around the lunch table. Much of this communication has informed which classes to flag and which faculty members to partner with. My aim was to identify classes and/or gatekeeping measures that address each gatekeeping assessment and/or frame.

\section{FRAMES AND ASSESSMENTS}

"Authority is Constructed and Contextual" examines context, culture, voice, and worldview. The two assessments that I thought exemplify this frame include the Texts in Context (TiC) paper for Hebrew Bible, which the faculty also identified as a gating assessment, and the final 
paper in Christian Ethics. I have not developed ways to assess these papers yet; however, I have created a rubric that ties to the frame "Information Creation as a Process." (Please see below.)

MTS Intro to New Testament Bibliographic Analysis Rubric

\begin{tabular}{|c|c|c|c|c|}
\hline & 1 & 2 & 3 & 4 \\
\hline $\begin{array}{l}\text { Number of sources } \\
\text { Scholarship as } \\
\text { Conversation }\end{array}$ & $\begin{array}{l}\text { Paper contains less } \\
\text { than } 3 \text { cited sources. }\end{array}$ & $\begin{array}{l}\text { Paper contains } \\
\text { between } 3 \text { and } 5 \text { cited } \\
\text { sources. }\end{array}$ & $\begin{array}{l}\text { Paper contains between } 6 \\
\text { and } 8 \text { cited sources. }\end{array}$ & $\begin{array}{l}\text { Paper contains more than } 8 \text { cited } \\
\text { sources. }\end{array}$ \\
\hline $\begin{array}{l}\text { Caliber of resources } \\
\text { Information Creation as } \\
\text { a Process } \\
\text { Scholarship as } \\
\text { Conversation }\end{array}$ & $\begin{array}{l}\text { Primarily cites sources } \\
\text { that fall into the } \\
\text { category of popular } \\
\text { literature. }\end{array}$ & $\begin{array}{l}\text { Cites articles from } \\
\text { popular literature, } \\
\text { general interest } \\
\text { publications, and } \\
\text { trade/professional } \\
\text { serials. Primarily cites } \\
\text { books that are more } \\
\text { than } 10 \text { years old. }\end{array}$ & $\begin{array}{l}\text { Cites articles from both } \\
\text { trade/professional } \\
\text { publications and scholarly, } \\
\text { peer-reviewed journals. } \\
\text { Cites books from well- } \\
\text { known commentary series } \\
\text { and reputable publishers. }\end{array}$ & $\begin{array}{l}\text { Primarily cites scholarly, peer- } \\
\text { reviewed articles and books from } \\
\text { well-known commentary series } \\
\text { and reputable publishers. }\end{array}$ \\
\hline $\begin{array}{l}\text { Diversity of sources } \\
\text { Authority is Constructed } \\
\text { \& Contextual } \\
\text { Scholarship as } \\
\text { Conversation }\end{array}$ & $\begin{array}{l}\text { Paper lacks diversity, } \\
\text { with sources either } \\
\text { coming from the same } \\
\text { author, publisher, } \\
\text { and/or journal }\end{array}$ & $\begin{array}{l}\text { Paper shows some } \\
\text { diversity with sources } \\
\text { coming from } 2 \text { to } 3 \\
\text { authors, publishers, } \\
\text { and/or journals. Cited } \\
\text { commentaries are } \\
\text { broad and focus on } \\
\text { more than } 1 \text { book of } \\
\text { the Bible. }\end{array}$ & $\begin{array}{l}\text { Paper shows diversity with } \\
\text { sources coming from } 3 \text { or } \\
\text { more authors, publishers, } \\
\text { and/or journals. Cited } \\
\text { commentaries focus on a } \\
\text { single book of the Bible. }\end{array}$ & $\begin{array}{l}\text { Paper shows diversity with } \\
\text { sources coming from } 4 \text { or more } \\
\text { authors, publishers, and/or } \\
\text { journals. Cited commentaries } \\
\text { focus on a single book of the } \\
\text { Bible. }\end{array}$ \\
\hline
\end{tabular}

The rubric measures three frames: "Authority is Constructed and Contextual," "Information Creation as a Process," and "Scholarship as Conversation." The rubric focuses on number of sources, types of sources, and diversity of sources, and is designed to be used with bibliographies from Intro to New Testament.

Identified as a gating assessment, the New Testament interpretation paper ties to three frames. For "Authority is Constructed and Contextual," I noted as a learning objective that students will be able to analyze and incorporate various viewpoints. The diversity of sources category attempts to measure this. The category caliber of resources maps to "Information Creation as a Process" and measures the quality of sources students use, with the emphasis here being placed on peer reviewed sources. As a learning outcome of "Scholarship as Conversation," I wrote, "Students will be able to synthesize and integrate secondary sources (articles, books, commentaries, etc.).” This learning objective speaks to all three rubric categories. In creating this rubric, the director of the MATS program and I collaborated closely. I had reached out to this professor and was hopeful that I would receive student bibliographies. Unfortunately, I do not think I will be receiving them since the professor has accepted a position at another institution. Moving forward, I may be able to use this rubric with student bibliographies from Hebrew Bible. 
I have more work to do with other frames, such as "Information has Value" and "Research as Inquiry." Discussions about plagiarism fall under the frame of "Information has Value," and I use an interactive plagiarism exercise with students in LinC. This is a course that all students, regardless of program, must take. In the future, I would like to explore ways to enhance this instruction and figure out how to best assess its impact. "Research as Inquiry" seems to be an easier frame to assess. The Hebrew Bible professor is an avid library supporter, so I look forward to working with her in the future to assess research proposals for her course.

Now I would like to return to Christian Theology. Based on the limited objectives for this course, I mapped the course only to one frame-“Scholarship as Conversation"-hoping that students can contribute to the conversation surrounding the theologians they study. The seminary faculty identified the final paper in this class as an important gatekeeping assessment. I believe a new faculty member is teaching this course, so the course objectives may well change. Regardless, I plan to contact the professor who teaches this course to see how we can collaborate in the future to meet class objectives.

One of my favorite frames is "Searching as Strategic Exploration." This frame is a natural fit for SEIP 950, the thesis prep class. The learning objective that I wrote for this frame is as follows: "Students will create a research log in order to record their search strategies, identifying where and how they have searched (e.g., the keywords and subject terms they have employed)." With input from both the dean and the director of MATS, I created a research log exercise that serves as a guide as students develop search strategies. Ideally, students will complete this research log over the course of the semester. The research log exercise encourages students to be mindful of how and where they are searching and urges them to record and reflect upon this process. Step two prompts students to use the University of Arizona's free mind mapping tool (http://www.library.arizona.edu/help/ tutorials/mindMap/) to create a concept map, which is often an important beginning step.

The second page of the research log contains a sample entry, including a screenshot of a very basic concept map. I distributed the research log exercise when I met with the students in SEIP 950 during the fall 2017 semester, and the professor was in favor of making 
this a course requirement. Although I did not receive any completed research logs, I will pursue this with the professor teaching the course in the fall.

As I was working on the research log exercise and having conversations with the dean, faculty members, and students, I noticed a need for additional exercises. As a result, I developed the research prescription. My inspiration for this worksheet came from a similar exercise developed by Fenwick Library at George Mason University. I have used this adapted one during one-on-one appointments with students and have found that it prompts students to not only think about the research process, but to take ownership of this process as well. Students are invited to brainstorm and identify keywords and subject terms. They are also encouraged to note where they are searching. Offering students something tangible that they can take with them after a research appointment also reinforces these sources and skills-at least I hope.

Overlap exists between the research prescription and the search strategies form; the search strategy exercise also encourages students to think about the search process and include citations. Both of these exercises can be mapped to "Research as Inquiry" and "Searching as Strategic Exploration.” In the curriculum mapping that I did for Intro to New Testament, I developed the following learning outcome for "Research as Inquiry": "Students will be able to use concordances and BibleWorks to aid in their interpretation of scripture." This could certainly be expanded to include commentaries, books, and articles. During the spring 2018 semester, I asked students in Intro to New Testament to complete this form at the end of their library session. Before I share these results, I would like to return to the research log recommendations for the thesis prep class.

Again there are similarities among this exercise and the search strategies form and the research prescription. However, I have attempted to scaffold these exercises, beginning with the research prescription, moving to the search strategies form, and culminating with the research log exercise. Ideally, I would like to gather longitudinal data, analyzing data from the search strategies form and comparing it to data from the research log recommendations. Clearly, this will take some time. My hope, however, is to show that, as students progress through the MATS program, their information literacy skills become more advanced. 
Working toward this goal, I have started with the data I have-from the search strategies form-and created a search strategy checklist. I am interested to see where students are searching and what modifications they are making to their search. The options included in the checklist represent concepts I covered during the library session.

Of the eight students, all searched a database. Three students made one modification to their search, and one student made five changes; the rest of the students fell somewhere in between. The most popular search modifications included refining by date and by source type (for example, checking the scholarly peer-reviewed box in the ATLA Religion Database); six students chose each of these options. Other common modifications included limiting to full text, as well as limiting to a particular language; both of these options were selected three times. Two students refined their searches by using subject terms. One student used the Scripture/Bible citation search feature in the ATLA Religion Database, and surprisingly, no students modified their search by adding another search term. Generally, I think of adding another keyword as the most basic way to modify a search, and this is a concept I cover with first-year undergraduates. Nonetheless, I was delighted to see some students chose more sophisticated limiters. I will keep all of this information in mind as I prepare to teach a future library session for Intro to New Testament.

\section{RECOMMENDATIONS}

Now that I have some data and some exercises, it only seems logical to reflect on the process. Therefore, I would like to offer a few suggestions. First, give yourself time and flexibility. Consider creating exercises and assessments that can be reused and easily repurposed; this is very important as changes in faculty impact course objectives, assignments, and programs. Also, try not to put too much pressure on yourself. The curriculum mapping that I have shared is still in many ways a work in progress. Another recommendation involves scalability and sustainability. Some important questions to consider include:

- How many librarians will participate in this project?

- How much time do you have to devote to this project?

I have the tendency to be overly ambitious. Starting with one program and/or one course makes a lot of sense, especially if only 
one librarian is working on this project. In my case, I am the primary librarian for the seminary, and technically, my time is split, with only a third dedicated to library responsibilities for the seminary. Moreover, it is hard and perhaps unrealistic to assess everything, so I am trying to focus on one new class a year. You may also want to create a timeline to aid in this process. The last thing you want to do is get overwhelmed and burned out before you even start. And last, but not least, determine measures that are meaningful for you and your institution. Meaningful measures will go a long way with buy-in from colleagues. After all, curriculum mapping is all about making connections and collaborating.

\section{NEXT STEPS}

In order to continue this work and to close the assessment loop, it is imperative to share my progress with the seminary faculty. I am meeting with the dean the end of June and will ask if I can have some time during either the opening meeting in August or a fall faculty meeting to share an update on the curriculum mapping and assessment. This may be a nice opening for future collaborations. During these meetings, I can highlight that I started with the overall gating assessments for the MATS degree and moved on to mapping course objectives from required classes to the Framework for Information Literacy for Higher Education. All of this information will be important to impart to the new director of the MATS program. I can also share the assessments and exercises I have created and the corresponding frames. For example, the rubric to assess bibliographies of New Testament interpretation papers maps to "Authority is Constructed and Contextual," "Information Creation as a Process," and "Scholarship as Conversation." The search strategy form for Intro to New Testament maps to "Research as Inquiry" and "Searching as Strategic Exploration," as does the research log for the thesis prep course SEIP 950. "Information has Value" is the remaining frame, which I have mapped to LinC, a class that is under revision. In addition to assessing the plagiarism exercise currently in LinC, I am especially interested in reaching out to the incoming MATS director, as well as the new faculty member teaching Christian Theology and Christian Ethics. Moreover, I do not want to overlook the existing Old Testament/Hebrew Bible professor. 
I certainly have my work cut out for me! Nonetheless, I will try to do this incrementally. Spreading the word is important, and at the very least, I can mention curriculum mapping and some of the exercises I have developed when I contact faculty members about scheduling a library session.

My end goal in all of this is to demonstrate that the library is a partner in learning. I would like to be able to show that through information literacy, students can meet not only gating assessments, but also course objectives. I would like to see those of you interested in curriculum mapping achieve this goal, too.

\section{RESOURCES}

Archambault, Susan Gardner, and Jennifer Masunaga. “Curriculum Mapping as a Strategic Planning Tool.” Journal of Library Administration 55, no. 6 (2015): 503-519.

Badke, William. "The Framework for Information Literacy and Theological Education: Introduction to the ACRL Framework." Theological Librarianship 8, no. 2 (October 2015): 4-7. https://theolib.atla.com/theolib/article/view/385

Baggett, Kevin, Virginia Connell, and Allie Thome. "Frame by Frame: Using the ACRL Framework for Information Literacy to Create a Library Assessment Plan." College \& Research Libraries News 79, no. 4 (5 April 2018). https://crln.acrl.org/index.php/ crlnews/article/view/16932/18640.

Oakleaf, Megan. “A Roadmap for Assessing Student Learning: Using the New Framework for Information Literacy for Higher Education." Journal of Academic Librarianship 40 (2014): 510-514.

Zingarelli-Sweet, Desirae. "Prepare a Way through the Wilderness: Transforming Library Instruction by Mapping the Curriculum.” Poster presented at the American Theological Library Association Conference, Long Beach, CA, June 17, 2016. 